\title{
The Relationship between Musical Aptitude, Self-efficacy and Achievement of Elementary School Pre-service Teachers
}

\author{
Seungyoun Hong \\ Gwangju National University of Education, Seoul, Korea \\ https://orcid.org/0000-0001-6438-8030
}

\begin{abstract}
The primary purpose of this study was to examine the selfefficacy of pre-primary teachers for musical aptitude, such as pitch and rhythm, and to examine whether there is a significant change in selfefficacy through individual practice and instruction of Chorubungen exercises for eight weeks. Another purpose of the study was to examine the relationship between the musical experience and musicality of preservice teachers, and their musical experience and achievement. To this end, a survey was conducted at the end of the semester for first-year students (56 males, 84 females) of a University of Education after regular individual practice in and guidance for eight weeks in the second semester of 2020. According to the results of the analysis, the positive selfefficacy of the pre-service teachers for pitch and rhythm before class participation was about $22.1 \%$ and $34.3 \%$ of the respondents, respectively, but after participating in the class, self-efficacy increased to $82.1 \%$ for pitch and $72.9 \%$ for rhythm. In comparison with the lower five variables, namely whether they learned an instrument among musical experiences $(t$-test) and the degree of singing ( $F$ test), pitch sensitivity $(t=2.41, p<.05)$, rhythm sensitivity $(\mathrm{t}=1.98, \mathrm{p}<.05)$, tempo sensitivity $(\mathrm{t}=2.79, \mathrm{p}<.01)$, major scale, and major harmony pattern sensitivity $(\mathrm{t}=2.67, \mathrm{p}<.01)$, all showed significant differences. In comparison to the achievement groups (chisquare test), differences between the achievement groups were measured based on whether they previously had experienced musical instruments $\left(\chi^{2}=10.11, \mathrm{p}<.01\right)$ and whether they had been active in a club $\left(\chi^{2}=8.70\right.$, $\mathrm{p}<.05)$.
\end{abstract}

Keywords: pre-service musical teachers; musical experience; musical aptitude; self-efficacy; Chorubungen exercises

\section{Introduction}

Along with the development of the 2015 revised curriculum of Korea, musical sensibility, musical creativity and fusion thinking, musical communication, cultural community, music information processing, and self-management 
competency are nurtured through music classes (Ministry of Education, 2015). Taking cognizance of the above features, music education is considered an essential goal of the course to build students' musicality, musical sensitivity, and musical creativity (Abeles et al., 1994; Hong, 2017).

It is a well-known fact that many of the students at the College of Education in Korea begin their elementary school pre-service life by ignoring the subjects related to arts and physical education, including music, under the school curriculum focused on entrance exams (Hong, 2013). As the pitch test, which had been enough to decide whether to enter the college of education 20 years ago, was removed from the entrance requirements, even students with a very low sense of pitch are admitted, complete the prescribed college curriculum, and become elementary school teachers teaching music.

The musical aptitude of pre-service teachers is also a very important issue to be considered. Gordon (2007) states that musical aptitude is a measure of an individual's potential to learn music, considering that instruments to measure musical aptitude mainly use melodies and rhythms. It cannot be denied that the sense of rhythm and pitch is the basis of musicality.

In terms of enhancing students' musical aptitude, the teacher's musical efficacy, which is the subject of music and education, acts as a very important variable (Jordon, 1999; 2005). Most previous studies related to the improvement of musicality focused on whether various musical activities affect musicality of children in early childhood or elementary school (Choi, 2018; Oh, 2009), and the efficacy of pre-primary schoolteachers' musicality.

If pre-service teachers with low musical aptitude graduate without a change in their musicality after entering college, the quality of their music classes cannot be guaranteed, and it will inevitably affect the development of students' musical aptitude (Kim, 2017; 2018). When instructing music classes, it is necessary to lay a foundation to enhance the self-efficacy and achievement of pre-service teachers by correcting or reinforcing their musical aptitude according to the level of prior experience and self-efficacy (Jang, 2021). According to the study, it was found that an individual's musical experience, especially the school experience, affects the individual's musical sense, music preference, and musical ability development even after school (Lim, 2015).

Results of prior studies on self-efficacy related to music, showed that pre-school teachers who had music-related hobbies and field practice experience had a high degree of music teaching efficacy (Koh et al., 2019), compared to the group of preprimary teachers' music experience and those who had no experience in music teaching (Yoon, 2018). This is not unrelated to research results that indicated that emotional responses to music may also appear sensitive or high, depending on age, musical experience, or musical training at school (Moon, 2008; Parker, 2010; Trousdale et al., 2010; Swanwick, 1973).

In addition, the result of the difference in self-efficacy in the subject music between 
the groups was significant $(\mathrm{t}=3.08, \mathrm{p}<.05)$ (Yoon, 2018a). A study on the relationship between music performance stress and self-efficacy in the subject music of pre-primary teachers also showed that distinct negative effects investigated were related (Yoon, 2013).

It was difficult to find prior studies on the degree of pre-service teachers' music aptitude, and whether their past musical experiences affected their musical aptitude. Most of all, no prior research could be found that determined whether sense of pitch and rhythm could be improved through eight weeks of individual Chorubungen practice. A need exists to study whether there is a way in which to improve pre-service teachers' musical aptitude and self-efficacy through one semester class within the curriculum of the college of education, or whether the method currently used by researchers can be an alternative.

In this study, instead of finding specific figures for the level of musical aptitude of elementary school pre-service teachers, the purpose was to investigate the extent of their self-efficacy for pitch and rhythm, which are the criteria for musical aptitude. Therefore, the kind of relationship that existed between the level of musical achievement of pre-service teachers and their good musical experiences, was examined, as well as the kind of relationship that existed between the level of musical achievement and the sense of musical self-efficacy.

The main contribution of this study is to determine the musical aptitude and selfefficacy of elementary school pre-service teachers, based on their sense of pitch and rhythm, and to investigate whether there was an improvement in self-efficacy through individual practice and guidance for eight weeks of Chorubungen, or SongonPitch, exercises which is the standard practice song collection for chorus practice, planned by the researcher.

In addition, the relationship between pre-service teachers' musical experience and musical self-efficacy, and the relationship between musical experience and achievement after eight weeks will be examined, and the results of this study will be used to increase the musical self-efficacy and achievement of elementary school pre-service teachers.

\section{Problem statement for and objectives of the study}

The problem addressed in this study deals with pre-primary school teachers' aptitude and self-efficacy (or lack thereof) to teach music at school.

The objectives of the study were: (i) to examine the self-efficacy of pre-primary teachers for musical aptitude; (ii) to examine whether there is a significant change in self-efficacy through individual practice and instruction of Chorubungen exercises for eight weeks, and (iii) to investigate the relationship between the musical experience and musicality of pre-service teachers, and their musical experience and achievement.

This study was intended to answer the following research questions: 1. What is the level of self-efficacy in musical aptitude of pre-primary teachers? 
2. Is there a correlation between the groups in terms of musical experience or the level of singing and listening to music?

3. Does the possibility exist to increase the degree of musical self-efficacy of elementary school pre-service teachers through individual practice and guidance for eight weeks of Chorubungen exercises?

\section{Literature review and limitations of the study}

\subsection{The Conceptual Framework}

This study is based on Gordon's Music Learning Theory. In Gordon's Music Learning Theory, audiation is the main concept, and there are eight types of audiation to increase musical aptitude (Gordon, 2005), namely

1. Listening to familiar or unfamiliar music.

2. Reading familiar or unfamiliar music.

3. Writing familiar or unfamiliar music from dictation.

4. Recalling and performing familiar music from memory.

5. Recalling and writing familiar music from memory.

6. Creating and improvising unfamiliar music while performing or in silence.

7. Creating and improvising unfamiliar music while reading.

8. Creating and improvising unfamiliar music while writing.

\subsubsection{Musical aptitude}

It is argued that musical aptitude is the potential ability to understand and make music, and that all people are born with musical aptitude, which can be developed according to the environment until around the age of nine, whereafter it becomes fixed (Gordon, 2007). Gordon's study revealed that most people's musical aptitude is in the middle of the normal distribution curve ( $z$ value $=0)$, and there are only a few people with very high or low musical aptitude ( $\mathrm{z}$ value $=-1,1,-2$, 2). The purpose of the measurement is to enable individualized instruction (easy, moderate, and difficult) according to the child's musical aptitude.

\subsubsection{Self-efficacy}

In psychology, self-efficacy is the expectation and belief that one can act appropriately in any situation (Bandura, 1977; 1986; 1997). This concept was proposed by Canadian psychologist Albert Bandura, and refers to a person's belief in his/her capacity to accomplish tasks required to achieve specific performances; people with high self-efficacy regard challenges as things that are to be mastered, rather than threats to avoid. Self-efficacy is also called self-efficacy expectation and belief in self-efficacy. Self-efficacy is not the same as knowing what to do. As a music pre-service teacher, having enough self-efficacy or not can make the difference between being successful in their music classes in the future, or not.

\subsection{Limitations of the study}

First, in the musical self-efficacy of pre-primary elementary teachers, using Gordon's sub-concepts of musical aptitude measurement tool, namely Tonal (tonal sense) and Rhythm (rhythm), the results of musical self-efficacy expanded to other music concepts; thus it is difficult to generalize. Second, the musical experiences of pre-service teachers in elementary school were focused on whether they learned to play a musical instrument or whether they participated in music- 
related club activities, and it is difficult to generalize significant differences with sub-variables about musical experience. Third, in eight weeks of Chorubungen practice and guidance, the practice and expression of accurate and sophisticated pitch and rhythm or time were not regarded as completion or achievement, but as a case of passing even a slight immature pitch or rhythm expression while confirming the practice of the study subjects.

\section{Data and methods}

\subsection{Research procedure and methods}

The method of this study is quantitative research, and the procedures of the study are as follows. First, reviewing previous studies in this study field, the musical experience, musical aptitude, and self-efficacy of elementary school pre-service teachers. Second, preparing a questionnaire to establish the relationship between the elementary school pre-service teachers' musical experience and individual achievement (musical aptitude-related self-efficacy). Third, individual practice was conducted for eight weeks using the Chorubungen practice songs for the research target students, while the contents of individual practices were checked every week. Fourth, a questionnaire was sent to the research target students through the department representative student three weeks before the class ended. The questionnaires were distributed and delivered in person or by e-mail at the end of the class. Fifth, excluding missing or erroneous response sheets, if necessary, frequency analysis or statistical analysis was conducted for each questionnaire to derive results to apply to the research problems. Results were discussed and suggestions made on meaningful parts based on the research results through analysis.

\subsection{Research tools}

\subsubsection{Chorubungen, a practice book for solfege}

As stated earlier, the researcher presented the subject Music Practice for 154 firstyear students during the second semester of the 2020 academic year. It is one of the courses designed to cultivate basic musical ability before learning the contents or methods of music and music education. The textbook used at the time was Chorubungen, a practice song book for solfege written by Wüllner (1871).

Wüllner (1832-1902), a German composer and conductor, wrote a textbook for reading and singing in 1871 while serving as the choral director of the Munich Conservatory. Starting with the scale and the name of the note, the 2nd to 7th tone interval, $\mathrm{C}$ major to various major compositions, key changes, and chromatic practice songs are presented as examples, which pre-service teachers also can start with. Table 1 shows the 8 -week programme for the Chorubungen exercises, a research tool used by the preparatory teachers participating in the study. 
Table 1: Chorubungen 8-week programme

\begin{tabular}{|c|c|c|}
\hline Week & Contents & Ref. \\
\hline 1 & $\begin{array}{l}\text { Application practice (\#12 a g) } \\
\text { 2nd, 3rd, tone-interval, section break, comma } \\
\text { length comprehension expression }\end{array}$ & \multirow{2}{*}{$\begin{array}{l}\text { achievement } \\
\text { (lower) }\end{array}$} \\
\hline 2 & $\begin{array}{c}\text { Application practice (\#13 a, b) } \\
\text { 2nd, 3rd, tie, syncopation practice }\end{array}$ & \\
\hline 3 & $\begin{array}{l}\text { Application practice (\#14 a g) } \\
\text { 2nd, 3rd, tie, syncopation practice }\end{array}$ & \multirow{3}{*}{$\begin{array}{l}\text { achievement } \\
\text { (middle) }\end{array}$} \\
\hline 4 & $\begin{array}{c}\text { Application practice (\#15 a f) } \\
\text { 4th, } 3 / 2,4 / 2,3 / 4 \text { meter }\end{array}$ & \\
\hline 5 & $\begin{array}{c}\text { Application practice }(\# 16 \mathrm{a} \sim \mathrm{d}) \\
4 \text { th, } 3 / 2,2 / 2,3 / 4 \text { meter }\end{array}$ & \\
\hline 6 & $\begin{array}{l}\text { Application practice }(\# 17 \mathrm{a} \sim \mathrm{h}) \\
\text { 4th, beat division, up \& down beats }\end{array}$ & \multirow{3}{*}{$\begin{array}{l}\text { achievement } \\
\text { (upper) }\end{array}$} \\
\hline 7 & $\begin{array}{l}\text { Application practice (\#18 a e) } \\
\text { 4th, dotted note, } 2 / 4,4 / 2 \text { meter }\end{array}$ & \\
\hline 8 & $\begin{array}{l}\text { Application practice }(\# 19 \mathrm{a} \sim \mathrm{h}) \\
3 / 8,6 / 8,6 / 4 \text { and } 3 / 2 \text { meter }\end{array}$ & \\
\hline
\end{tabular}

\subsubsection{The questionnaire}

As shown in Table 2 below, the questionnaire used to collect data consisted of a space in which the respondent was identified (class, number, and gender), and the participant's class achievement. It further contained questions about whether participants played musical instruments, attended music-related clubs, and enjoyed singing and listening to music before entering the school. The questionnaire comprised a total of 20 items, divided into six areas, and related questions were asked so that the contents could be explored. All questions were in closed-ended form, except for four questions, to which a clause was added to allow for free answers. A 5-point Likert-type agreement scale $(1=$ strongly disagree, $5=$ strongly agree) was used for all except the two questions asking about simple experience. Specific questionnaire items are shown in Table 2 below.

Table 2: Questionnaire contents and questions

\begin{tabular}{|c|c|c|}
\hline Division & Contents & Questions \\
\hline $\begin{array}{l}\text { Respondent } \\
\text { Characteristic }\end{array}$ & $\begin{array}{l}\text { Grade, class, gender } \\
\text { Individual Achievement Level }\end{array}$ & $\begin{array}{l}\text { Basic } \\
\text { questions }\end{array}$ \\
\hline $\begin{array}{l}\text { Before } \\
\text { attending } \\
\text { class } \\
\text { Self-efficacy } \\
\text { for pitch and } \\
\text { rhythm }\end{array}$ & $\begin{array}{l}\text { - The degree to which one can sing the major scale with } \\
\text { the correct pitch } \\
\text { - The degree to which the harmony pattern of the major } \\
\text { triad in major can be sung with the correct pitch } \\
\text { - Degree of accuracy or sensitivity to pitch } \\
\text { - Degree of accuracy or sensitivity to rhythm } \\
\text { - Degree of accuracy or sensitivity to the sense of beat }\end{array}$ & $\# 1 \sim \# 5$ \\
\hline $\begin{array}{l}\text { After } \\
\text { attending }\end{array}$ & $\begin{array}{l}\text { - Whether you think the pitch has improved after } \\
\text { individual practice of Chorubungen pieces ( } 8 \text { weeks) }\end{array}$ & \#6 \#9 \\
\hline
\end{tabular}




\begin{tabular}{|c|c|c|}
\hline $\begin{array}{l}\text { class for pitch } \\
\text { and rhythm } \\
\text { self-efficacy }\end{array}$ & $\begin{array}{l}\text { - Whether you think your sense of rhythm has } \\
\text { improved after individual practice of Chorubungen } \\
\text { pieces ( } 8 \text { weeks) } \\
\text { - Whether you think the sense of time has improved } \\
\text { after individual practice for Chorubungen pieces (8 } \\
\text { weeks) } \\
\text { - Whether the presence or absence of a name in the } \\
\text { score affects one's own score }\end{array}$ & \\
\hline $\begin{array}{l}\text { Experience } \\
\text { learning an } \\
\text { instrument }\end{array}$ & $\begin{array}{l}\text { - Any experience learning musical instruments before } \\
\text { entering college? } \\
\text { - Any experience with musical instruments? } \\
\text { - How long have you been learning an instrument? } \\
\text { - Did the experience of learning an instrument affect the } \\
\text { development of pitch and rhythm? }\end{array}$ & \#10 \#13 \\
\hline $\begin{array}{l}\text { Experience in } \\
\text { music club } \\
\text { activities }\end{array}$ & $\begin{array}{l}\text { - Experience in music-related clubs in elementary, middle, } \\
\text { and high school? } \\
\text { - Type of music club? } \\
\text { - Period of activity in the music club? }\end{array}$ & \#18 \#20 \\
\hline $\begin{array}{l}\text { Affinity for } \\
\text { music }\end{array}$ & $\begin{array}{l}\text { - Whether you like to listen to music } \\
\text { - The type of music you like to listen to }\end{array}$ & \#16 \#17 \\
\hline $\begin{array}{l}\text { Affinity for } \\
\text { singing }\end{array}$ & $\begin{array}{l}\text { - Do you like to sing? } \\
\text { - What type of songs do you like to sing? }\end{array}$ & $\# 14 \sim \# 15$ \\
\hline
\end{tabular}

\subsection{Data collection and analysis}

For this study, questionnaires were distributed to 154 students from the end of November to the beginning of December 2020, and by mid-December, 142 people responded in writing or by e-mail. Two of the 142 responses were excluded from analysis due to their lack of suitability for analysis and the research. All respondents in this research survey were first-year students at an Educational University in Korea. Regarding the gender of the participants, the demographic data of the respondents collected indicated that 56 male students $(40.0 \%)$ and 84 female students $(60 \%)$ participated. Table 3 indicates how the Chorubungen practice songs were used to divide participants into groups according to their individual achievement. Group A comprised the respondents who completed the applied practice song (based on the editing of Sekwang Music Publishing Co.), No. 17 or higher. Respondents who completed the exercises a-g or 16-a-d were grouped in the relatively middle-performing group, and group $\mathrm{C}$ comprised the respondents who completed the applied exercises $12 \mathrm{a}-\mathrm{g}$ or $13 \mathrm{a}-\mathrm{b}$. The frequency and composition ratio of the groups were $35(25.0 \%)$ for group A, $50(35.7 \%)$ in group $B$, and $55(39.7 \%)$ in group $C$.

For the analysis, using the SPSS 25 program, the t-test was used to determine the influence of learning a musical instrument among musical experiences, and the Ftest was used to compare this with the five lower variables according to the degree of singing. Pitch sensitivity, rhythm sensitivity, beat sensitivity, major scale and major harmony pattern sensitivity were tested by $t$. A chi-square test was performed to compare the differences among the groups in terms of achievement according to the experience of musical instruments and the presence or absence of club activities. 
Table 3: Group of Chorubungen Practice Achievement

\begin{tabular}{|c|c|c|c|c|}
\hline \multirow{2}{*}{$\begin{array}{c}\text { Division } \\
\text { Group }\end{array}$} & \multicolumn{2}{|c|}{ Frequency $(\mathrm{N})$} & \multirow{2}{*}{$(\mathrm{N})$} & \multirow{2}{*}{$(\%)$} \\
\cline { 2 - 3 } & Male & Female & & \\
\hline Group A (upper) & 4 & 31 & 35 & 25.0 \\
\hline Group B (middle) & 22 & 28 & 50 & 35.7 \\
\hline Group C (under) & 30 & 25 & 55 & 39.3 \\
\hline Total & 56 & 84 & 140 & 100 \\
\hline
\end{tabular}

\section{Results}

\subsection{Degree of self-efficacy in musical aptitude of pre-service teachers}

The degree of self-efficacy for the study subjects on pitch before class participation is shown in Table 4 for male and female students. $40.7 \%$ of the respondents said that their sense of pitch before participating in class was 'very low' or 'low', while about $22.1 \%$ of the respondents' responded 'high' or 'very high'. Of these, only $2.1 \%$ were found to measure very high, indicating a sense of efficacy for their own pitch.

Table 4: Degree of self-efficacy on pitch before class participation

\begin{tabular}{|c|c|c|c|c|c|c|}
\hline $\begin{array}{c}\text { Degree } \\
\text { Division }\end{array}$ & $\begin{array}{c}\text { Very } \\
\text { low }\end{array}$ & Low & Usual & High & $\begin{array}{c}\text { Very } \\
\text { high }\end{array}$ & Sum \\
\hline Male (\%) & 3 & 16 & 21 & 13 & 1 & $56(40.0)$ \\
\hline Female (\%) & 7 & 31 & 31 & 15 & 2 & $84(60.0)$ \\
\hline Sum (\%) & $10(7.1)$ & $47(33.6)$ & $52(37.1)$ & $28(20.0)$ & $3(2.1)$ & $140(100.0)$ \\
\hline
\end{tabular}

The degree of self-efficacy in the study subjects regarding the sense of rhythm prior to class participation is shown in Table 5, for male and female students separately. Of the respondents $32.8 \%$ responded that their sense of rhythm before participating in the class was 'very low' or 'low', whereas $34.3 \%$ of the respondents were of the opinion that their sense of pitch was 'high' or 'very high'. The selfefficacy in rhythm was somewhat higher than that for pitch.

Table 5: Degree of self-efficacy for the sense of rhythm before class participation

\begin{tabular}{|c|c|c|c|c|c|c|}
\hline Div. & $\begin{array}{c}\text { Very } \\
\text { low }\end{array}$ & Low & Average & High & $\begin{array}{c}\text { Very } \\
\text { high }\end{array}$ & Sum \\
\hline Male frequency (\%) & 5 & 12 & 18 & 19 & 4 & $56(40.0)$ \\
\hline Female frequency (\%) & 3 & 26 & 28 & 21 & 3 & $84(60.0)$ \\
\hline Sum (\%) & $8(5.7)$ & $38(27.1)$ & $46(32.9)$ & $40(29.3)$ & $7(5.0)$ & $140(100.0)$ \\
\hline
\end{tabular}


The degree of self-efficacy of the students on whether they were able to sing the major scale with the correct pitch before participating in the class is shown in Table 6, for male and female students separately. Before participating in class, $46.4 \%$ of the respondents said that their self-efficacy for the major scale was 'very negative' or 'negative', indicating that it was difficult to sing the major scale with the correct pitch, while about $28.5 \%$ of the respondents indicated that their sense of efficacy for the scale was 'high' or 'very high'. However, in reality, of these, only $6.4 \%$ showed a very positive sense of efficacy for their scale.

Table 6: Degree of self-efficacy for the sense of major tonality before class participation

\begin{tabular}{|c|c|c|c|c|c|c|}
\hline div. & $\begin{array}{c}\text { very } \\
\text { low }\end{array}$ & low & average & high & $\begin{array}{c}\text { very } \\
\text { high }\end{array}$ & sum \\
\hline Male frequency (\%) & 12 & 32 & 15 & 14 & 4 & $77(40.0 \%)$ \\
\hline Female frequency (\%) & 10 & 11 & 20 & 17 & 5 & $63(60.0)$ \\
\hline Sum (\%) & $22(15.7)$ & $43(30.7)$ & $35(25.0)$ & $31(22.1)$ & $9(6.4)$ & $140(100.0)$ \\
\hline
\end{tabular}

The degree of self-efficacy on their ability to sing the harmonic patterns (IVI-IVVI) for the major triads with the correct pitch before participating in the class also was calculated separately for male and female students, as indicated in Table 7. More than half of the respondents, namely $57.9 \%$, responded that their selfefficacy in expressing their major harmonic patterns before class participation was 'very negative' or 'negative', revealing that it was difficult to sing the harmonic patterns with the correct pitches. About $20.7 \%$ of respondents answered that their sense of efficacy for expressing their major harmonic patterns was 'high' or 'very high'. Of these latter respondents, only $5.7 \%$ showed a very positive sense of efficacy for the progression.

Table 7: Degree of self-efficacy for the major chord progression before class participation

\begin{tabular}{|c|c|c|c|c|c|c|}
\hline measure & $\begin{array}{c}\text { very } \\
\text { low }\end{array}$ & low & average & high & $\begin{array}{c}\text { very } \\
\text { high }\end{array}$ & sum \\
\hline Male frequency (\%) & 12 & 17 & 11 & 11 & 4 & $55(40.0 \%)$ \\
\hline Female frequency (\%) & 15 & 37 & 19 & 10 & 4 & $85(60.0 \%)$ \\
\hline Sum (\%) & $27(19.3)$ & $54(38.6)$ & $30(21.4)$ & $21(15.0)$ & $8(5.7)$ & $140(100.0 \%)$ \\
\hline
\end{tabular}

\subsection{Relationship between musical experience and sub-variables}

Table 8 below depicts the responses of 114 (37 male students, 77 female students) who had handled or learned to play musical instruments before entering university and who thought their musical instrument experience influenced the development of pitch and rhythm. Although $5.1 \%$ of the respondents answered 
that they had no or little effect on their development of pitch and rhythm despite their experience of learning a musical instrument, $67.5 \%$ of the respondents answered that the experience of musical instruments developed their sense of pitch and rhythm. Of these, $27.1 \%$ answered 'very much', recognizing that the musical experience through an instrument is a variable that directly affects the development of musicality.

Table 8: Degree of influence on the development of pitch/rhythm with musical instrument experience

\begin{tabular}{|c|c|c|c|c|c|c|}
\hline Miv. & $\begin{array}{c}\text { Very } \\
\text { little }\end{array}$ & Little & Average & Some & $\begin{array}{c}\text { Very } \\
\text { much }\end{array}$ & Sum \\
\hline Male frequency (\%) & 1 & 1 & 9 & 16 & 10 & $37(32.2)$ \\
\hline Female frequency (\%) & 0 & 4 & 22 & 30 & 21 & $77(67.8)$ \\
\hline Sum (\%) & $1(0.7)$ & $5(3.6)$ & $31(22.1)$ & $46(32.9)$ & $31(22.1)$ & $114(100.0)$ \\
\hline
\end{tabular}

Instrumental experience $\mathrm{N}=114(\mathrm{M}=37, \mathrm{~F}=77)$

Table 9 below examines the relationship between sub-variables such as pitch sensitivity, rhythm sensitivity, beat sensitivity, major scale expression, and major harmony pattern according to whether the study subjects dealt with or learned musical instruments before entering college. They were compared and analysed for significance with the corresponding sub-variables.

It is shown that the experience of learning a musical instrument was related to all sub-variables. First, in the pitch sensitivity part, the $t$-value was 2.41 between the group who had learned the instrument and the group that did not, so there was a significant difference, depending on the experience of the instrument. In the rhythm sensitivity part, it was 1.98 , showing a significant difference. Also, it was found to be 2.22, which was significant (95\% confidence level). Moreover, in the major scale expression part and the tempo sensitivity part, the $t$-test results showed that the values were 2.67 and 2.79, showing significance at the $99 \%$ confidence level.

Table 9: Comparison of sub-variables with instrumental experience

\begin{tabular}{|l|c|c|c|c|c|c|c|}
\hline \multirow{2}{*}{ Experience } & \multicolumn{2}{|c|}{ Yes (112) } & \multicolumn{2}{c|}{ No (28) } & \multirow{2}{*}{$\mathrm{t}$} & \multicolumn{2}{c|}{ Total } \\
\cline { 4 - 5 } \cline { 5 - 8 } & $\mathrm{M}$ & $\mathrm{SD}$ & $\mathrm{M}$ & $\mathrm{SD}$ & & $\mathrm{M}$ & $\mathrm{SD}$ \\
\hline $\begin{array}{l}\text { Expressing major } \\
\text { scale }\end{array}$ & 2.86 & 1.16 & 2.21 & 1.03 & $2.67^{* *}$ & 2.73 & 1.16 \\
\hline Chord progression & 2.60 & 1.13 & 2.07 & 1.05 & $2.22^{*}$ & 2.49 & 1.13 \\
\hline Tone sensitivity & 2.86 & 0.92 & 2.39 & 0.87 & $2.41^{*}$ & 2.76 & 0.93 \\
\hline Rhythm sensitivity & 3.09 & 0.98 & 2.68 & 1.02 & $1.98^{*}$ & 3.01 & 1.00 \\
\hline Meter sensitivity & 3.10 & 0.95 & 2.54 & 0.96 & $2.79^{* *}$ & 2.99 & 0.97 \\
\hline
\end{tabular}


Table 10 depicts the findings of the analysis of the comparison of the sub-variables as experienced by participants who, before entering university, had experienced club activities, and those who had not. Based on whether the study subjects had experienced club activities, subordinate variables such as pitch sensitivity, rhythm sensitivity, beat sensitivity, major scale expression, and major harmony pattern were investigated. The relationship with the variable was examined, and the significance of the sub-variable was compared and analysed through the $t$-test.

In the pitch sensitivity part, the $t$ value was 1.56 between the group with experience in club activities and the group without club activity, so there was no significant difference. On the other hand, in the rhythm sensitivity part, it was 2.93 , showing a significant difference at the $99 \%$ confidence level. In the rest of the major scale expression, major harmony pattern, and tempo sensitivity, the values of $t$-test were 1.87, 0.72 , and 1.70; thus, there was no significant difference.

Table 10: Comparison of sub-variables with club activity experience

\begin{tabular}{|l|c|c|c|c|c|}
\hline \multirow{2}{*}{ division } & \multicolumn{2}{|c|}{ Yes (36) } & \multicolumn{2}{c}{ No (104) } & \multirow{2}{*}{$\mathrm{t}$} \\
\cline { 2 - 5 } & $\mathrm{M}$ & $\mathrm{SD}$ & $\mathrm{M}$ & $\mathrm{SD}$ & \\
\hline $\begin{array}{l}\text { Expressing major } \\
\text { scale }\end{array}$ & 3.03 & 1.00 & 2.63 & 1.20 & 1.81 \\
\hline Chord progression & 2.61 & 0.99 & 2.45 & 1.18 & 0.72 \\
\hline Tone sensitivity & 2.97 & 1.00 & 2.69 & 0.89 & 1.56 \\
\hline Rhythm sensitivity & 3.42 & 0.91 & 2.87 & 0.99 & $2.93^{* *}$ \\
\hline Meter sensitivity & 3.22 & 0.93 & 2.90 & 0.98 & 1.70 \\
\hline$* *$ * $p<.01$
\end{tabular}

Table 11 below compares and analyses the relationship between sub-variables such as pitch sensitivity, rhythm sensitivity, tempo sensitivity, major scale expression, and major harmony pattern, according to the degree to which the study subjects enjoyed listening to music. The ANOVA F-test shows the significance with the corresponding sub-variable.

In the sub-variable major scale expression part, the $\mathrm{F}$ value was 3.27 between the group who listened to music a lot and the group that did not, and there was a significant difference. As a result of the verification, the values were 1.44, 0.33, 0.99 and 0.07 , showing no significant difference.

Table 11: Comparison of sub-variables with a habit of listening to music

\begin{tabular}{|l|c|c|c|c|c|c|c|}
\hline \multirow{2}{*}{$\begin{array}{r}\text { Listening to } \\
\text { music }\end{array}$} & \multicolumn{2}{|c|}{ Usual (23) } & \multicolumn{2}{c|}{ Much (36) } & Very much (81) & \multirow{2}{*}{$F$} \\
\cline { 2 - 8 } & $\mathrm{M}$ & $\mathrm{SD}$ & $\mathrm{M}$ & $\mathrm{SD}$ & $\mathrm{M}$ & $\mathrm{SD}$ & \\
\hline Expressing major scale & 2.39 & 0.84 & 2.47 & 1.13 & 2.94 & 1.16 & $3.27^{*}$ \\
\hline Chord progression & 2.52 & 1.03 & 2.22 & 0.98 & 2.60 & 1.21 & 1.44 \\
\hline
\end{tabular}




\begin{tabular}{|l|c|c|c|c|c|c|c|}
\hline Tone sensitivity & 2.74 & 0.86 & 2.67 & 0.83 & 2.81 & 0.99 & 0.33 \\
\hline Rhythm sensitivity & 2.78 & 1.08 & 2.94 & 0.83 & 3.10 & 1.04 & 0.99 \\
\hline Meter sensitivity & 2.91 & 0.95 & 3.00 & 0.89 & 3.00 & 1.03 & 0.07 \\
\hline
\end{tabular}

Table 12 below shows that there is a significant correlation in all sub-variables except for the major harmonic pattern variable in the comparative analysis with sub-variables according to the degree of singing. First, in the expression part of the major scale, which is a sub-variable, the F value was 6.69 between the group who liked to sing and the group who did not, revealing a significant difference at the $99 \%$ confidence level. Then, in pitch and rhythm sensitivity, the F-values were 8.44 and 5.95, respectively, between the group who liked to sing and the group who did not, showing a significant difference at the $99 \%$ confidence level. In the beat sensitivity part, the $\mathrm{F}$ value was 3.60 , which showed a significant difference at the $95 \%$ confidence level.

Table 12: Comparison of sub-variables with a habit of singing songs

\begin{tabular}{|l|c|c|c|c|c|c|c|}
\hline \multirow{2}{*}{ Singing songs } & \multicolumn{2}{|c|}{ less (33) } & \multicolumn{2}{c|}{ usual (36) } & \multicolumn{2}{c|}{ much (71) } & \multirow{2}{*}{ F } \\
\cline { 2 - 8 } & $\mathrm{M}$ & $\mathrm{SD}$ & $\mathrm{M}$ & $\mathrm{SD}$ & $\mathrm{M}$ & $\mathrm{SD}$ & \\
\hline Expressing major scale & 2.61 & 1.22 & 2.22 & 0.76 & 3.04 & 1.21 & $6.69^{* *}$ \\
\hline Chord progression & 2.27 & 1.00 & 2.25 & 0.99 & 2.72 & 1.20 & 2.95 \\
\hline Tone sensitivity & 2.58 & 0.83 & 2.36 & 0.83 & 3.06 & 0.92 & $8.44^{* *}$ \\
\hline Rhythm sensitivity & 2.79 & 1.02 & 2.67 & 0.89 & 3.28 & 0.97 & $5.95^{* *}$ \\
\hline Meter sensitivity & 2.91 & 1.04 & 2.67 & 0.89 & 3.18 & 0.95 & $3.60^{*}$ \\
\hline
\end{tabular}

${ }^{*} p<.05,{ }^{* *} p<.01$

\subsection{Awareness of the degree of self-efficacy improvement after 8 weeks of Chorubungen exercises}

The tables and contents below elucidate whether the study subjects thought their pitch, and rhythm improved while practising the music in the Chorubungen textbook for eight weeks, as well as their perception of the improvement in selfefficacy. The subjects practised as many pieces of music as they could each week as assignments, and after classifying the songs they had practised during class, they went through the process of classifying them as 'pass' or 're-practise'.

Table 13 is the result of answering the question about whether they thought their pitch had improved while practising Chorubungen pieces for eight weeks. Of the study subjects, $82.1 \%$ answered that their pitch had improved or improved significantly while practising Chorubungen pieces for eight weeks, suggesting that improvement in self-efficacy for pitch was perceived very positively. On the 
other hand, only $3.6 \%$ of the respondents expressed a negative perception, namely that their pitch did not improve even through music practice. The results in the table are provided according to gender group.

Table 13: Degree of improvement in self-efficacy for pitch

\begin{tabular}{|l|c|c|c|c|c|}
\hline Miv. & $\begin{array}{c}\text { neg. \& } \\
\text { very neg. }\end{array}$ & average & positive & $\begin{array}{c}\text { very } \\
\text { positive }\end{array}$ & sum \\
\hline Male frequency (\%) & 3 & 10 & 34 & 9 & $56(40.0)$ \\
\hline Female frequency (\%) & 2 & 10 & 53 & 19 & $84(60.0)$ \\
\hline Sum (\%) & $5(3.6)$ & $20(14.3)$ & $87(62.1)$ & $28(20.0)$ & $140(100.0)$ \\
\hline
\end{tabular}

Table 14 shows the results of responses to the question of whether the study subjects thought their sense of rhythm had improved while practising Chorubungen pieces for eight weeks. Of the subjects, $72.9 \%$ answered that their sense of rhythm had improved or improved very much while practising Chorubungen pieces for eight weeks. On the other hand, only $5.0 \%$ of the respondents expressed a negative perception that their sense of rhythm did not improve even through music practices.

Table 14: Degree of improvement in self-efficacy for rhythm

\begin{tabular}{|l|l|l|l|l|l|}
\hline Measure & $\begin{array}{l}\text { neg. \& } \\
\text { very neg. }\end{array}$ & average & positive & $\begin{array}{l}\text { very } \\
\text { positive }\end{array}$ & sum \\
\hline Male frequency (\%) & 4 & 13 & 28 & 11 & $56(40.0)$ \\
\hline Female frequency (\%) & 3 & 18 & 46 & 17 & $84(60.0)$ \\
\hline Sum (\%) Measure & $\begin{array}{l}\text { neg. \& } \\
\text { very neg. }\end{array}$ & average & positive & $\begin{array}{l}\text { very } \\
\text { positive }\end{array}$ & sum \\
\hline Div. & $4(5.0)$ & $31(22.1)$ & $74(52.9)$ & $28(20.0)$ & $140(100.0)$ \\
\hline Male frequency (\%) & 4 & 13 & 28 & 11 & $56(40.0)$ \\
\hline Female frequency (\%) & 3 & 18 & 46 & 17 & $84(60.0)$ \\
\hline Sum (\%) & $7(5.0)$ & $31(22.1)$ & $74(52.9)$ & $28(20.0)$ & $140(100.0)$ \\
\hline
\end{tabular}

The following is a comparison according to achievement groups (high, middle, low), in terms of whether they had experienced musical instruments, whether they had participated in club activities, and how much they enjoyed listening to music and singing. In this case, the chi-square test method is used. Table 15 below compares and analyses the correlation with the achievement group according to the presence or absence of musical instrument experience. The result of the chisquare test, $\chi^{2}=10.11$ and $p<.01$, indicates that there was a difference between the groups. 
Table 15: Comparison between musical instrument experience and achievement

\begin{tabular}{|c|c|c|c|}
\hline Experience & Yes & No & Sum \\
\hline Group A (upper) & 32 & 3 & 35 \\
& $(91.4)$ & $(8.6)$ & {$[25.0]$} \\
\hline Group B (middle) & 44 & 7 & 51 \\
& $(86.3)$ & $(13.7)$ & {$[36.4]$} \\
\hline Group C (under) & 36 & 18 & 54 \\
& $(66.7)$ & $(33.3)$ & {$[38.6]$} \\
\hline sum & 112 & 28 & 140 \\
& {$[80.0]$} & {$[20.0]$} & {$[100]$} \\
\hline
\end{tabular}

$\chi^{2}=10.11, p<.01$

Table 16 below compares and analyses the correlation between the achievement group according to the presence or absence of club activities. The result of the chisquare test, $\chi^{2}=8.70$ and $\mathrm{p}<.05$, indicates a difference between groups. It is significant that if one does not have club activities, one still can belong to achievement groups $\mathrm{B}$ and $\mathrm{C}$.

Table 16: Comparison between music club activities

\begin{tabular}{|c|c|c|c|}
\hline Experience & Yes & No & Sum \\
\hline Group A (upper) & 14 & 21 & 35 \\
& $(40.0)$ & $(60.0)$ & {$[25.0]$} \\
\hline Group B (middle) & 15 & 36 & 51 \\
& $(29.4)$ & $(70.6)$ & {$[36.4]$} \\
\hline Group C (under) & 7 & 47 & 54 \\
& $(13.0)$ & $(87.0)$ & {$[38.6]$} \\
\hline Sum & 36 & 104 & 140 \\
& {$[25.7]$} & {$[74.3]$} & {$[100]$} \\
\hline
\end{tabular}

$\chi^{2}=8.70, p<.05$

Table 17 below compares and analyses the correlation between the group achievement according to the degree of music enjoyment. The result of the chisquare test, $x^{2}=3.26, p>.05$, did not indicate any difference between groups. In other words, the degree of enjoyment of music did not have a significant effect on the achievement group.

Table 17: Comparison between listening to music and achievement

\begin{tabular}{|c|c|c|c|c|}
\hline \multicolumn{2}{|c|}{ Listening to music } & Not much & Usual & Much \\
\hline Group/ N. (\%) & $\begin{array}{c}35 \\
{[25.0]}\end{array}$ & $\begin{array}{c}7 \\
(20.0)\end{array}$ & $\begin{array}{c}9 \\
(25.7)\end{array}$ & $\begin{array}{c}19 \\
(54.3)\end{array}$ \\
\hline Group B (middle) & $\begin{array}{c}26 \\
{[51.0]}\end{array}$ & $\begin{array}{c}10 \\
(19.6)\end{array}$ & $\begin{array}{c}15 \\
(29.4)\end{array}$ & $\begin{array}{c}26 \\
(51.0)\end{array}$ \\
\hline
\end{tabular}




\begin{tabular}{|c|c|c|c|c|}
\hline Group C (under) & $\begin{array}{c}54 \\
{[38.6]}\end{array}$ & $\begin{array}{c}6 \\
(11.1)\end{array}$ & $\begin{array}{c}12 \\
(22.2)\end{array}$ & $\begin{array}{c}36 \\
(66.7)\end{array}$ \\
\hline \multirow{2}{*}{ Sum } & 140 & 23 & 36 & 81 \\
& {$[100]$} & {$[16.4]$} & {$[25.7]$} & {$[57.9]$} \\
\hline
\end{tabular}

$\chi^{2}=3.26, p>.05$

Table 18 below compares and analyses the correlation with the achievement in each group according to the degree of pleasure gained from singing. The findings of the chi-square test, $\chi^{2}=6.45$ and $p>.05$, indicated no difference between groups. In other words, the degree of singing enjoyment did not have a significant effect on the achievement group. It shows that even if the degree of singing enjoyment was high, it still was possible to be classified in achievement groups B and C, and at the same time, it shows that people with a low or moderate level of enjoyment can also belong to the groups $\mathrm{B}$ and $\mathrm{C}$.

Table 18: Comparison between favouring singing and achievement

\begin{tabular}{|c|c|c|c|c|}
\hline \multicolumn{2}{|c|}{ Favouring singing } & Not much & usual & much \\
\hline \multirow{2}{*}{ Group/ N. (\%) } & 35 & 5 & 7 & 23 \\
& {$[25.0]$} & $(14.3)$ & $(20.0)$ & $(65.7)$ \\
\hline \multirow{2}{*}{ Group B (middle) } & 26 & 12 & 12 & 27 \\
& {$[51.0]$} & $(23.5)$ & $(23.5)$ & $(52.9)$ \\
\hline \multirow{2}{*}{ Group C (under) } & 54 & 16 & 17 & 21 \\
& {$[38.6]$} & $(29.6)$ & $(31.5)$ & $(38.9)$ \\
\hline \multirow{2}{*}{ Sum } & 140 & 33 & 36 & 71 \\
& {$[100]$} & {$[23.6]$} & {$[25.7]$} & {$[50.7]$} \\
\hline
\end{tabular}

$\chi^{2}=6.45, p>.05$

\section{Discussion}

After practising Chorubungen music pieces for eight weeks, $82.1 \%$ of the study subjects responded that their self-efficacy for pitch had improved, showing an increased rate of more than $60 \%$ compared to the $22.1 \%$ who answered that they had a high self-efficacy before participating in the class. Self-efficacy for rhythm also showed an increase of more than $38.6 \%$ compared to $34.3 \%$ that answered that they had a high sense of self-efficacy before participating in class, as $72.9 \%$ of respondents answered that they had improved after eight weeks of practice. Selfefficacy for the sense of beat also showed an increase of $40.8 \%$ or more compared to $34.2 \%$ who answered that they had a high sense of self-efficacy before participating in the Chorubungen class, as $75.0 \%$ of the respondents answered that they had improved after eight weeks' practice.

A correlation was found between the experience of learning an instrument and all five sub-variables, and in the pitch sensitivity part, the $t$ value was 2.41 between the group with and without the experience of learning an instrument, indicating a significant difference depending on experiencing the instrument. In the sensitivity part, it was shown as 1.98 , showing a significant difference, and in the major harmony pattern, it was shown as 2.22, which was significant (95\% 
confidence level). Moreover, in the major scale expression part and the tempo sensitivity part, the t-test results showed that the values were 2.67 and 2.79, showing significance at the $99 \%$ confidence level.

In the comparative analysis of sub-variables indicating whether there had been club activity or not, the $t$ value of 1.56 between the groups with and without club activity experience indicated that in the pitch sensitivity part, no significant difference was found, but, on the other hand, the value in the rhythm sensitivity part was 2.93 . Here a significant difference was found at the $99 \%$ confidence level. In the remaining major scale expression, major harmony pattern, and tempo sensitivity, the values of the t-test were $1.87,0.72$, and 1.70 , indicating no significant difference.

The comparative analysis findings with sub-variables such as pitch sensitivity, rhythm sensitivity, tempo sensitivity, major scale expression, and major harmony pattern according to the level of music enjoyment, showed that the group that usually listens to music a lot in the sub-variable major scale expression part showed a significant difference between the group with the F value of 3.27, but in the remaining major harmony patterns, pitch sensitivity, rhythm sensitivity, and tempo sensitivity, the $\mathrm{F}$ value was $1.44,0.33,0.99$, and 0.07 , indicating that no significant difference was observed.

The comparative analysis with sub-variables according to the degree of usual singing indicated a significant correlation in all sub-variables except for the major harmonic pattern variable. First, in the expression part of the major scale, which is a sub-variable, the F value was 6.69 between the group who liked to sing and the group who did not like singing, revealing a significant difference at the $99 \%$ confidence level. Then, in pitch and rhythm sensitivity, the F-values were 8.44 and 5.95 , respectively, between the group who liked to sing and the group who did not, showing a significant difference at the $99 \%$ confidence level. In the beat sensitivity part, the $\mathrm{F}$ value was 3.60 , which showed a significant difference at the 95\% confidence level.

In comparing the groups by achievement, musical instrument experience, club activity experience, music enjoyment level, and singing level were comparatively analysed as dependent variables, and the significance of differences between groups was examined based on the chi-square test result. The correlation with the achievement group according to the experience of musical instruments was compared and analysed. As a result of the chi-square test, $\chi^{2}=10.11, \mathrm{p}<.01$, was recognized, the correlation between the groups was recognized, and the correlation with the achievement group according to the experience of club activities was evaluated. As a result of comparative analysis, the chi-square test result also showed $\mathrm{p}<.05$ at $\chi^{2}=8.70$, indicating a difference between groups.

A significant finding was that if participants did not have club activity experience, they still could belong to achievement groups B (in achievement) and C (under achievement). This is a comparative analysis of the correlation with the achievement group according to their degree of enjoyment of music. As a result 
of the chi-square test, $p>.05$ at $\chi^{2}=3.26$, the difference between the groups was not recognized. There was a significant difference in the achievement group according to the degree of enjoyment of music. As a result of comparative analysis of the correlation with the achievement group according to the degree of singing enjoyment, the chi-square test result showed that $\chi^{2}=6.45$ and $p>.05$, so no difference was recognized between groups.

\section{Conclusion}

The study found that only $22.1 \%$ of the respondents believed that pre-service teachers' self-efficacy for pitch before class participation was high, indicating that most of the respondents $(78 \%)$ had a low self-efficacy for pitch. Self-efficacy for rhythmic sense was higher than that of pitch, as $34.3 \%$ answered that it was high, but the remaining about $64 \%$ showed no high sense of efficacy for rhythmic sense. Their self-efficacy of the sense of beat was high at $34.2 \%$, which is in congruence with the sense of rhythm. The self-efficacy of the major scale was $28.5 \%$ positive, but $71.5 \%$ showed that the self-efficacy was not high for the major scale. In addition, only $20.7 \%$ of the respondents answered positively in terms of selfefficacy for harmonious progression in a major key, while the remaining almost $80 \%$ indicated low self-efficacy for harmonious progression patterns.

Based on the results of this study, the following conclusions can be made. First, although most of the students entering the College of Education had a low selfefficacy for pitch, rhythm, and rhythm related to musical aptitude, self-efficacy could be positively improved through eight weeks' individual practice. Second, depending on the individual's musical environment, such as 'how much you usually sing' and 'whether you have learned or experienced an instrument', it is possible to express major scale and harmonic progression patterns, or to affect sensitivity to pitch, rhythm, and beat. However, there was no significant difference regarding 'experience of club activities' or 'usually listening to music'. Third, as the difference between groups was recognized in the relationship between achievement groups in the group with instrumental experience, it was found that instrumental experience played a more positive role in enhancing students' musical self-efficacy than other musical experiences.

\section{References}

Abeles, H. F., Hoffer, C. R., \& Klotman, R. H. (1994). Foundations of music education. Schirmer Books.

Bandura, A. (1977). Self-efficacy: Toward a unifying theory of behavioral change. Psychological Review, 84(2), 191-215. https://doi.org/10.1037/0033-295x.84.2.191

Bandura, A. (1986). Social foundations of thought and action: A social cognitive theory. Englewood Cliffs, NJ: Prentice-Hall. https://doi.org/10.5465/amr.1987.4306538

Bandura, A. (1997). Self-efficacy: The exercise of control. New York, NY: W. H. Freeman.

Choi, J. W. (2018). The Effects of Music Activity Using Dalcroze Eurhythmics on Infant Musicality Improvement. Comprehensive Arts and Music, 2(1), 117-118.

Gordon, E. E. (2007). Learning sequences in music: A contemporary learning theory. Chicago, IL: GIA Publications, Inc.

Gordon, E. E. (2005). Music aptitude and related test: An introduction. Chicago, IL: GIA Publications. Hong, S. Y. (2017). An analyzing study of partial 2 part-chorus in the 5 and 6th grades' 
music textbooks. Korean Journal of Music Education Technology, 30, 55-72. https://doi.org/10.30832/Jmes.2017.30.55

Hong, S. Y. (2013). A preliminary study on instructional methods of singing activities based on Gordon's music learning theory: Concentrated on the 3rd grade in elementary school. Korean Journal of Research in Music Education, 42(3), 357-385.

Jang, S. O. (2021). Trends of Early Childhood Pre-Service Teachers' Research related to Self-Efficacy. Korean Association for Learner-centered Curriculum and Instruction, 21(1), 685-687.

Jordon, J. M. (2005). Evoking sound: The choral warm-up methods, procedures, planning, and core vocal exercises. Chicago, IL: GIA.

Jordon, J. M. (1999). The Musician's Soul. Chicago, IL: GIA.

Kim, Y. A. (2017). Using small groups' effect of rehearsal plan of elementary school choir. (Master's thesis). [Gyeongin] National University of Education, South Korea.

Kim, H. Y. (2018). A study on elementary school choir rehearsal techniques for teachers. (Master's thesis). Korea National University of Education, South Korea.

Koh, S. A., Kim, M. J., \& Kim, N. Y. (2019). A Study on Pre-service Early Childhood Teachers' Music Self-concept and Music Teaching Efficacy according as Experiences related to Music. Korean Association for Learner-centered Curriculum and Instruction, 19(21), 995-998.

Lim, E. J. (2015). Significant Influences of School Music Experiences on one's Musical Development during School Years and Beyond. Research in Music Pedagogy, 15, 201.

Ministry of Education. (2015). Ministry of Education Notice No. 2015-74 [Annex 12]. Seoul, Korea.

Moon, J. Y. (2008). A Study on the Relation of Gender, Age, and Musical Experience with Emotional Response to Music. Music and Culture, 19, 158-160. https://doi.org/10.17091/kswm.2008.19.147

Oh, N. R. (2009). A Survey on the Influence of Musical Education before the Age of 9 on the Development of Musical Talent. Comprehensive Arts and Music, 3, 115.

Parker, E. C. (2010). Exploring student experiences of belonging within an urban high school choral ensemble: An action research study. Music Education Research, 12(4), 339-352. https://doi.org/10.1080/14613808.2010.519379

Swanwick, K. (1973). Musical cognition and aesthetic response. Psychology of Music, 1(2), 7-13. https://doi.org/10.1177/030573567312001

Trousdale, A., Bach, E., \& Willis, E. (2010). Freedom, physicality, friendship and feeling: Aspects of children's spirituality expressed through the choral reading of poetry. International Journal of Children's Spirituality, 15(4), 317-329. https:// doi.org/10.1080/1364436x.2010.529874

Yoon, G. K. (2018). A Study on the Correlation between Music Performance Stress and Elementary Pre-Service Teacher's Music Education Self-Efficacy. Korean Journal of Research in Music Education, 45(1), 139-141. https://doi.org/10.30775/kmes.47.1.06

Yoon, G. K. (2018a). A Study on the Correlations Between Elementary Pre-Service Teacher`s Music Subject Self-Efficacy and Previous Experience about Music Education. Korean Journal of Research in Music Education, 45(4), 129-131.

Yoon, M. J. (2013). Orff Instrumental Ensemble Programs and Self-Efficacy of Pre-service Teachers. Korean Journal of Music Education Technology, 17, 12-13.

Wüllner, F. (1871). Chorubungen: Choir exercises at the Munich School. [Chorubungen] Translated by [Sekwang] Music Publishing Co. 